\title{
JUSTICE BRENT E. DiCKSON, STATE CONSTITUTIONAL INTERPRETATION, AND THE RELIGION PROVISIONS OF THE INDIANA CONSTITUTION
}

\author{
Michael J. DeBoeR*
}

\section{INTRODUCTION}

In 1989, in an article published in one of this law school's journals, Indiana Chief Justice Randall T. Shepard issued a call for renewed attention to the Indiana Constitution. ${ }^{1}$ In that article, he encouraged lawyers to present and judges to consider arguments based on the Indiana Constitution. He wrote, "The ability of [the Indiana Supreme Court] and other Indiana courts to write good law about the Indiana Bill of Rights depends in important part upon good lawyering by those who appear before us." $\mathrm{He}$ added, "The protection of Americans against tyranny requires that state supreme courts and state constitutions be strong centers of authority on the rights of the people." ${ }^{3}$ When Chief Justice Shepard issued this call, Justice Brent E. Dickson had been a member of the Indiana Supreme Court and had served together with him for about three years. ${ }^{4}$

During their lengthy, overlapping tenures on the court, ${ }^{5}$ both Justices contributed profoundly to the development of Indiana constitutional law. ${ }^{6}$ Both

* Associate Professor of Law, Faulkner University, Thomas Goode Jones School of Law. LL.M., summa cum laude, 2011, Indiana University Robert H. McKinney School of Law; J.D., magna cum laude, 1998, Valparaiso University School of Law; Law Clerk to Justice Brent E. Dickson of the Indiana Supreme Court, 1998-2000.

The author thanks Indiana University Robert H. McKinney School of Law for the invitation to participate in its special program entitled A Tribute to Justice Brent Dickson's Contributions to Indiana Constitutional Law. This Article is a revised version of the talk the author gave during that program on March 29, 2016. The author also thanks the Indiana Law Review for its interest in publishing the presentations given at that event and for its careful editorial work.

1. Randall T. Shepard, Second Wind for the Indiana Bill of Rights, 22 IND. L. REV. 575, 580 (1989) (calling for a refocusing of attention on the Indiana Constitution).

2. Id. at 584 .

3. Id. at 586 .

4. Justice Dickson served from January 6, 1986 to April 29, 2016 and as Chief Justice from May 15, 2012 to August 18, 2014. Justice Shepard served from September 6, 1985 to March 23, 2012 and as Chief Justice from March 4, 1987 to March 23, 2012. See Supreme Court Justices, MYCOURTS, https://mycourts.in.gov/JR/Default.aspx [https://perma.cc/HX4R-FART] (last visited July 13, 2016).

5. They served together for over twenty-six years.

6. They served with colleagues who also made important contributions to Indiana constitutional law. For instance, Justice Alfred J. Pivarnik interpreted and applied article 1, section 32 (recognizing the right to bear arms for the defense of one's self and the state) in Kellogg v. City of Gary, 562 N.E.2d 685 (Ind. 1990). Justice Jon D. Krahulik interpreted and applied article 1, section 12 (recognizing a right to remedy by due course of law) in State v. Rendleman, 603 N.E.2d 1333 (Ind. 1992). Likewise, Justice Frank Sullivan, Jr. interpreted an array of Indiana constitutional 
gave careful attention to the method of state constitutional interpretation, placing a heavy emphasis on the constitutional text and the history surrounding the adoption of the Indiana Constitution. ${ }^{7}$ Both also wrote important constitutional decisions that will guide legislators, executive officials, judges, lawyers, and citizens in Indiana for many years to come. ${ }^{8}$ Together they did what Chief Justice

provisions, including article 1, sections 12 and 23 (recognizing a right to remedy by due course of law and prohibiting the granting of unequal privileges and immunities, respectively) in Indiana High School Athletic Ass'n v. Carlberg, 694 N.E.2d 222 (Ind. 1997), article 1, section 14 (recognizing a criminal defendant's right against self-incrimination) in Bush v. State, 775 N.E.2d 309 (Ind. 2002), article 1, section 19 (recognizing the jury's right in a criminal case to determine the law and the facts) in Seay v. State, 698 N.E.2d 732 (Ind. 1998), and article 2, sections 8 and 12 (authorizing the General Assembly to disenfranchise "any person convicted of an infamous crime" and exempting electors from arrest while voting, respectively) in Snyder v. King, 958 N.E.2d 764 (Ind. 2011). Also, Justice Myra C. Selby interpreted and applied article 1, section 12 (requiring courts to be open and recognizing a right to remedy by due course of law) and article 1, section 23 (prohibiting the Indiana General Assembly from granting unequal privileges and immunities) in Martin v. Richey, 711 N.E.2d 1273 (Ind. 1999). Justice Theodore R. Boehm interpreted and applied an array of Indiana constitutional provisions, including article 1, sections 9 and 12 (recognizing a right to speak, write, and print freely and a right to remedy by due course of law, respectively) in Cantrell v. Morris, 849 N.E.2d 488 (Ind. 2006), article 1, section 11 (recognizing a right against unreasonable searches and seizures) in Edwards v. State, 759 N.E.2d 626 (Ind. 2001), article 1, sections 12 and 23 (recognizing a right to open courts and a right to remedy and prohibiting the Indiana General Assembly from granting unequal privileges and immunities, respectively) in McIntosh v. Melroe Co., 729 N.E.2d 972 (Ind. 2000), article 1, section 12 (recognizing a right to remedy by due course of law) in Sanchez v. State, 749 N.E.2d 509 (Ind. 2001), and article 4, sections 22 and 23 (prohibiting the Indiana General Assembly from enacting special legislation and requiring it to make general laws when general laws can be made applicable) in Municipal City of South Bend v. Kimsey, 781 N.E.2d 683 (Ind. 2003). Justice Robert D. Rucker interpreted and applied article 1, section 19 (recognizing the right of the jury to determine the law and the facts in criminal cases) in Warren v. State, 725 N.E.2d 828 (Ind. 2000), and Holden v. State, 788 N.E.2d 1253 (Ind. 2001), article 1, section 20 (recognizing the right to a jury trial in civil cases) in Jordan v. Deery, 778 N.E.2d 1264 (Ind. 2002), and article 8, section 1 (imposing a duty on the Indiana General Assembly to provide for a general and uniform system of common schools) in Nagy v. Evansville-Vanderburgh Sch. Corp., 844 N.E.2d 481 (Ind. 2006). The justices who have more recently joined the court (Chief Justice Loretta H. Rush, Justice Steven H. David, Justice Mark S. Massa, and Justice Geoffrey G. Slaughter) will continue to make contributions to Indiana constitutional law.

7. See infra Part II.

8. For a list of some of Chief Justice Shepard's important Indiana constitutional law opinions, see Chief Justice Brent E. Dickson, A Tribute to Randall T. Shepard; Justice, Indiana Supreme Court, 1985-2012; Chief Justice of Indiana, 1987-2012, 45 IND. L. REV. 585, 585 n.5 (2012). As this Article and other articles published in this Tribute demonstrate, Justice Dickson wrote opinions touching on a wide range of Indiana constitutional issues and rights, including the rights to worship and exercise religion freely (City Chapel Evangelical Free Inc. v. City of South Bend, 944 N.E.2d 443 (Ind. 2001)), to remedy by due course of law (McIntosh v. Melroe Co., 729 
Shepard's article indicated he was determined to do-they helped to make "the Indiana Constitution and the Indiana Supreme Court ... strong protectors of [the] rights [of the people]."

Justice Dickson's contributions to Indiana constitutional law grew out of his longstanding interest in history and government. As a student at Purdue University, he studied American history and government, ${ }^{10}$ and then he studied law at Indiana University Robert H. McKinney School of Law. ${ }^{11}$ When he was practicing law in Lafayette, Indiana, he served as president and was on the board of governors of the Tippecanoe County Historical Association. ${ }^{12}$ His interest in Indiana history and government is also evident in articles he wrote recounting Indiana's constitutional history and discussing the role of lawyers and judges in writing the Indiana Constitution. ${ }^{13}$ Additionally, his regard for Indiana history and government is apparent from his service as an adjunct professor at the Indiana University law schools at Bloomington and Indianapolis where he, for more than a decade, taught Indiana constitutional law and the history surrounding the adoption of Indiana's first and second constitutions. ${ }^{14}$

This Article does not, however, study Justice Dickson's contributions to Indiana constitutional law generally. Instead, it focuses on his opinions in three cases in which he interpreted and applied several of the seven religion provisions

N.E.2d 972, 985 (Ind. 2000) (Dickson, J., dissenting); Journal-Gazette Co. v. Bandido's, Inc., 712 N.E.2d 446, 473 (Ind. 1999) (Dickson, J., dissenting)), and to have a jury trial (Sims v. United States Fidelity \& Guaranty Co., 782 N.E.2d 345, 354 (Ind. 2003) (Dickson, J., dissenting); Dixie v. State, 726 N.E.2d 257 (Ind. 2000)); the right against double jeopardy (Richardson v. State, 717 N.E.2d 32 (Ind. 1999)); and the freedom from unreasonable searches and seizures (Grier v. State, 868 N.E.2d 443 (Ind. 2007)). Although he addressed the government's constitutional right and obligation to provide for the peace, safety, and well-being of Indiana citizens (City Chapel Evangelical Free Inc. v. City of South Bend, 944 N.E.2d 443 (Ind. 2001); Clinic for Women, Inc. v. Brizzi, 837 N.E.2d 973, 988 (Ind. 2005) (Dickson, J., concurring in result)), he also interpreted the constitutional prohibition against the Indiana General Assembly granting privileges or immunities that are not equally available to all (Collins v. Day, 644 N.E.2d 72 (Ind. 1994)), and the requirement that the legislative and executive branches provide a property tax system characterized by uniformity, equality, and just valuation of property (Boehm v. Town of St. John, 675 N.E.2d 318 (Ind. 1996); State Board of Tax Commissioners v. Town of St. John, 702 N.E.2d 1034 (Ind. 1998)).

9. Shepard, supra note 1, at 586.

10. Amy Patterson-Neubert, Indiana Supreme Court Justice to Speak on State Constitutions, Purdue News SERV. (Apr. 19, 2005), http://www.purdue.edu/uns/html3month/2005/050419. Hurt.Dickson.html [http://perma.cc/PM4R-48FX].

11. See Michael J. DeBoer, Brent E. Dickson, January 6, 1986-Present, in Justices of THE Indiana Supreme Court 401, 402 (Linda C. Gugin \& James E. St. Clair eds., 2011).

12. Id.; Brent E. Dickson, Indiana's Constitutional Past, 68 Ind. Hist. Bull. I, I (1997), http://www.in.gov/history/files/constpast.pdf [https://perma.cc/4QBM-FXHX].

13. See, e.g., Brent E. Dickson, Lawyers and Judges as Framers of Indiana's 1851 Constitution, 30 IND. L. REv. 397 (1997); see also Dickson, supra note 12, at i-viii.

14. See Courts in the Classroom, Justice Brent E. Dickson, http://www.in.gov/judiciary/ citc/2829.htm [https://perma.cc/4P5Y-M6CG] (last visited Sept. 22, 2016). 
of the Indiana Constitution: City Chapel Evangelical Free Inc. v. City of South Bend,$^{15}$ Embry v. O'Bannon, ${ }^{16}$ and Meredith v. Pence.$^{17}$ His opinions in these three cases provide insight into the court's and his method of constitutional interpretation, and they explicate the meaning of several of Indiana's religion provisions.

This study develops in several steps. First, it discusses the aforementioned three Indiana Supreme Court cases. ${ }^{18}$ Second, it explores the court's method of state constitutional interpretation, which he helped to bring into sharper focus. ${ }^{19}$ Third, it analyzes his interpretation of several religion provisions in these cases. ${ }^{20}$ Fourth, it concludes with some observations regarding his careful application of the court's interpretive method and key features of the court's religion provisions jurisprudence. ${ }^{21}$

\section{The Three CAses And Decisions}

The Indiana Bill of Rights includes seven separate provisions regarding religious freedom, ${ }^{22}$ and Justice Dickson interpreted and applied several of the seven provisions in three cases that came before the Indiana Supreme Court during his tenure. In City Chapel, the court considered a church's appeal of a trial court's order overruling the church's objections to condemnation proceedings instituted by the City of South Bend. ${ }^{23}$ The church argued that the condemnation proceedings violated its rights under article 1, sections 2, 3, and 4 of the Indiana Constitution and the First Amendment to the United States Constitution. ${ }^{24}$ The church also argued that the City of South Bend could not use its eminent domain power and condemn the church's property without the court conducting a hearing to balance the competing interests. ${ }^{25}$ The city argued that Indiana's religious freedom provisions should be equated with the First Amendment and that the trial court's order should be affirmed because the condemnation action was religionneutral and because no balancing test or hearing was required. ${ }^{26}$ The city also argued that Indiana's religion provisions only apply to the personal devotional aspect of religion. ${ }^{27}$

15. 744 N.E.2d 443 (Ind. 2001).

16. 798 N.E.2d 157 (Ind. 2003).

17. 984 N.E.2d 1213 (Ind. 2013).

18. See infra Part II.

19. See infra Part III.

20. See infra Part IV.

21. See infra Part V.

22. See IND. Const. art. 1, §§ 2-8. Although the Indiana Bill of Rights includes seven separate provisions, several of these provisions include multiple clauses or components.

23. City Chapel Evangelical Free Inc. v. City of S. Bend, 744 N.E.2d 443, 444 (Ind. 2001).

24. Id. at 445 .

25. Id. at 451 .

26. Id. at 445 .

27. Id. 
In his opinion for the court, Justice Dickson, joined by Justice Robert D. Rucker, determined that the church was entitled to an opportunity to present its claim that the city's condemnation proceedings imposed a material burden on core values embodied in the Indiana Bill of Rights. ${ }^{28}$ Chief Justice Shepard concurred in Justice Dickson's opinion as to the religious freedom claims under the Indiana Constitution. ${ }^{29}$ However, he concluded that the church's claim under the First Amendment did not constitute a hybrid claim, and that the trial court did not err in overruling objections without holding a hearing on the federal constitutional claim. ${ }^{30}$

Justice Frank Sullivan, Jr. dissented with a separate opinion, expressing his view that the church had not adequately demonstrated a right to an evidentiary hearing. ${ }^{31}$ Justice Theodore R. Boehm also dissented with a separate opinion. $\mathrm{He}$ agreed with the majority in several respects: the various religion provisions of the Indiana Constitution prevent Indiana government "from imposing material burdens on the exercise of religious practice"; "this protection extends beyond the private devotion vel non of individuals and also includes the public and group activities associated with religious practices"; and the city "may not exercise its right of eminent domain in such a way as to materially burden City Chapel's religious activities. ${ }^{32} \mathrm{He}$ concluded, however, that City Chapel had not presented a claim that its religious activities were materially burdened, ${ }^{33}$ that the church's complaint was closer to a claim under the takings provision of the Indiana Constitution, ${ }^{34}$ that the church was not entitled to a hearing because it had not presented a claim that bars the taking, ${ }^{35}$ and that the church had not stated a hybrid claim under the First Amendment. ${ }^{36}$

In Embry, the court considered a challenge by taxpayers to the state's dualenrollment program, which permitted nonpublic school students enrolled in at least one specific class in a public school corporation to be counted in that school corporation's average daily membership. ${ }^{37}$ Under this program, participating public school corporations can enter into dual-enrollment agreements with private schools and provide various secular instructional services (such as courses in fitness and health, art, foreign language, study skills, verbal skills, music, and computer technology) to private school students on the premises of private schools and receive additional funding for the enrollment of those students. ${ }^{38}$ The challengers argued that the dual-enrollment program violated article 1, section 6

28. Id. at 450-51.

29. Id. at 454 (Shepard, C.J., concurring).

30. Id. at 454-55.

31. Id. at 455-56 (Sullivan, J., dissenting).

32. Id. at 456 (Boehm, J., dissenting).

33. Id. at 456-57.

34. Id. at 457.

35. Id. at 458 .

36. $I d$.

37. Embry v. O’Bannon, 798 N.E.2d 157, 158-59 (Ind. 2003).

38. Id. at 159. 
of the Indiana Constitution by money being drawn from the state treasury to benefit parochial schools. ${ }^{39}$

In his opinion for the court, Justice Dickson, joined by Justice Rucker, determined first that the taxpayers had standing under the public standing doctrine ${ }^{40}$ Second, he found that the dual-enrollment program did not provide any substantial benefit to the participating parochial schools or directly fund activities of a religious nature. ${ }^{41} \mathrm{He}$ thus concluded that the program did not violate article 1 , section $6 .{ }^{42}$

Chief Justice Shepard concurred in the result reached by Justice Dickson. ${ }^{43}$ Justice Sullivan concurred on the standing issue but concurred only in the result as to the article 1, section 6 question. ${ }^{44}$ Justice Sullivan wrote a separate opinion addressing the standing question, and Chief Justice Shepard concurred in Justice Sullivan's opinion. ${ }^{45}$ Justice Boehm concurred in the result, and he wrote a separate opinion, in which Justice Sullivan concurred. ${ }^{46}$ In his opinion, Justice Boehm expressed agreement with the majority as to its disposition of the standing issue and its holding that "expenditure of public funds for proper educational purposes is not 'for the benefit of' a religious institution even if the delivery point of the educational services is a parochial school." ${ }^{47}$ Justice Boehm disagreed, however, with the majority's reasoning that article 1, section 6 did not foreclose the public funding of parochial or sectarian schools; instead, he believed that article 1 , section 6 "stands squarely against that proposition." 48

In Meredith, the court considered a challenge to Indiana's Choice Scholarship Program, ${ }^{49}$ which provides vouchers ("choice scholarships") to eligible parents so that they have the choice to send their children to a public school, a charter school, or a qualified private school. ${ }^{50}$ The challengers argued that Indiana's school voucher program violated three separate provisions of the Indiana Constitution-article 8, section 1 (of the Education Article), and article 1, sections 4 and 6 (two religion provisions of the Indiana Bill of Rights). ${ }^{51}$ More specifically, the challengers argued that the program "uses taxpayer funds to pay for the teaching of religion to Indiana schoolchildren and [that] it purports to provide those children's publicly funded education by paying tuition for them to

39. Id. at $159-60$.

40. Id.

41. Id. at $158,167$.

42. Id.

43. Id. at 167 (Shepard, C.J., concurring in result).

44. Id. (Sullivan, J., concurring in part).

45. Id. at 167-69.

46. Id. at 167,170 (Boehm, J., concurring in result).

47. Id. at 169 .

48. Id. at 170 .

49. The Indiana General Assembly enacted this program in 2011. See Choice Scholarship Program, Pub. L. No. 92-2011, § 10, Ind. Acts 1024 (2011) (codified at IND. CoDE § 20-51-4).

50. Meredith v. Pence, 984 N.E.2d 1213 (Ind. 2013).

51. Id. at 1217 . 
attend private schools rather than the "general and uniform system of Common Schools' the [Indiana] Constitution mandates."

In an opinion written by Chief Justice Dickson, the court unanimously determined that the program did not violate any of these provisions of the Indiana Constitution. ${ }^{53}$ As to the challenge under article 8 , section $1,{ }^{54}$ the court concluded that the program adopted by the Indiana General Assembly "appears to fall under the first imperative" or affirmative duty imposed by the Education Article upon the Indiana legislature to encourage moral, intellectual, scientific, and agricultural improvement, "and not the second" imperative or affirmative duty to provide by law for a general and uniform system of open common schools without tuition. ${ }^{55}$ The program, the court found, does not implicate the second imperative and the Indiana General Assembly's specific task thereunder. ${ }^{56}$ As to the challenge under article 1, section 4, the court held that the program does not compel individuals to attend, erect, or support places of worship or ministry. ${ }^{57}$ As to the challenge under article 1 , section 6 , the court held that the program does not impermissibly provide direct benefits to religious institutions. ${ }^{58}$

\section{The Court's Methodology of State Constitutional INTERPRETATION}

In his opinions in City Chapel, Embry, and Meredith, Justice Dickson articulated the Indiana Supreme Court's methodology for interpreting and applying provisions of the Indiana Constitution. ${ }^{59}$ He drew his particular articulation of the court's methodology from his dissenting opinion in McIntosh

52. Id. (quoting Brief for Respondents at 12).

53. Id. at 1217, 1230-31.

54. Because this Article focuses on Justice Dickson's religion provisions jurisprudence, it will not provide an extended analysis of his education provision jurisprudence.

55. Meredith, 984 N.E.2d at 1220-21, 1224-25.

56. Id. at 1224-25.

57. Id. at $1225-26$.

58. Id. at $1229-30$.

59. Id. at 1218. He stated that the Court's methodology requires:

a search for the common understanding of both those who framed it and those who ratified it. Furthermore, the intent of the framers of the Constitution is paramount in determining the meaning of a provision. In order to give life to their intended meaning, we examine the language of the text in the context of the history surrounding its drafting and ratification, the purpose and structure of our constitution, and case law interpreting the specific provisions. In construing the constitution, we look to the history of the times, and examine the state of things existing when the constitution or any part thereof was framed and adopted, to ascertain the old law, the mischief, and the remedy. The language of each provision of the Constitution must be treated with particular deference, as though every word had been hammered into place.

Id. at 1218 (quoting Embry v. O'Bannon, 798 N.E.2d 157, 160 (Ind. 2003) (quoting City Chapel Evangelical Free, Inc. v. City of South Bend, 744 N.E.2d 443, 447 (Ind. 2001))). 
v. Melroe Co., where he had earlier restated the court's methodology.$^{60}$ His (and the court's) interpretive method has several elements:

(1) The court searches for the common understanding of a constitutional provision that was shared by the framers and the ratifiers. ${ }^{61}$

(2) The court keeps paramount in interpreting a provision the intended meaning of the framers. ${ }^{62}$

(3) To give effect to the framers' intended meaning, the court carefully examines the language of the text, taking into consideration several additional factors:

(a) The historical context in which the text was drafted and ratified;

(b) The Indiana Constitution's purpose and structure; and

(c) The case law interpreting the constitutional provision. ${ }^{63}$

(4) The court studies the broader historical context and the "state of things existing" at the time the constitution or any specific provision was drafted and adopted, seeking to ascertain the intended meaning from several additional inputs:

(a) "The old law";

(b) "The mischief"; and

60. See 729 N.E.2d 972, 986 (Ind. 2000) (Dickson, J., dissenting). In his opinion for the court in McIntosh, Justice Boehm expressed his agreement with Justice Dickson's articulation of the court's interpretive methodology. He wrote: "We agree with the dissent that the various frequently invoked constitutional talismans - constitutional text, history of the times, intent of the framers, etc.- - are proper keys to the interpretation of Article I, Section 12." Id. at 974 (citing Ajabu v. State, 693 N.E.2d 921, 928-29 (Ind. 1998); Collins v. Day, 644 N.E.2d 72, 75-76 (Ind. 1994)). Consequently, their disagreement was not over interpretive method, but rather over the meaning and the application of article 1, sections 12 and 23.

61. Meredith, 984 N.E.2d at 1218 (quoting Embry, 798 N.E.2d at 160 (quoting City Chapel, 744 N.E.2d at 447)). The City Chapel opinion, the first in this series of opinions, reveals that Justice Dickson drew his articulation of the court's method from his dissenting opinion in McIntosh, 729 N.E.2d at 986 (Dickson, J., dissenting). In his Meredith opinion, Justice Dickson also cited Nagy v. Evansville-Vanderburgh School Corp., 844 N.E.2d 481, 484 (Ind. 2006), as additional authority for this methodology. In Nagy, Justice Rucker, writing for the court, quoted Justice Dickson's McIntosh articulation of the court's method of interpretation and cited Ratliff v. Cohn, 693 N.E.2d 530, 534 (Ind. 1998), in which Justice Dickson, writing for the court, had similarly stated the court's method.

62. Meredith, 984 N.E.2d at 1218 (quoting Embry, 798 N.E.2d at 160 (quoting City Chapel, 744 N.E.2d at 447$))$.

63. Id. 
(c) "The remedy." 64

(5) The court gives particular deference to the language chosen by the framers on the assumption that they selected the terms with care. ${ }^{65}$

In his McIntosh opinion, where he provided a restatement of the court's methodology, Justice Dickson cited various Indiana Supreme Court cases in which the court had stated its methodology and recognized the various elements. ${ }^{66}$ As to the first element (searching for the common understanding of the framers and the ratifiers), he cited his 1994 opinion in Collins v. Day and Chief Justice Shepard's 1991 opinion in Bayh v. Sonnenburg. ${ }^{67}$ In support of the second element (keeping the framers' intended meaning paramount), he quoted language from his 1996 opinion in Boehm v. Town of St. John and Chief Justice Richard M. Givan's 1985 opinion in Eakin v. State ex rel. Capital Improvement Board of Managers of Marion County. ${ }^{68}$ For the third element (examining the language of the text, taking into account its history, the constitution's purpose and structure, and case law interpreting the provision), he quoted language from Chief Justice Shepard's 1994 opinion in Indiana Gaming Commission v. Moseley and cited Shepard's 1993 opinion in Price v. State and Shepard's 1988 opinion in State Election Board v. Bayh. ${ }^{69}$ As to the fourth element (looking to the history of the

64. Id.

65. Id.

66. 729 N.E.2d at $985-86$.

67. Id. (citing Collins v. Day, 644 N.E.2d 72, 75-76 (Ind. 1994); Bayh v. Sonnenburg, 573 N.E.2d 398, 412 (Ind. 1991)). In Collins, Justice Dickson wrote: "Properly interpreting a particular provision of the Indiana Constitution involves a search for the common understanding of both those who framed it and those who ratified it." 644 N.E.2d at 75-76 (citing Sonnenburg, 573 N.E.2d at 412). In Sonnenburg, Chief Justice Shepard wrote: "This Court has regarded the task of interpreting particular provisions of the Indiana Constitution as a search for the common understanding of both those who framed it and those who ratified it." 573 N.E.2d at 412 (internal citations omitted).

68. McIntosh, 729 N.E.2d at 986 (quoting Boehm v. Town of St. John, 675 N.E.2d 318, 321

(Ind. 1996); Eakin v. State ex rel. Capital Improvement Bd. of Managers of Marion Cty., 474

N.E.2d 62, 64 (Ind. 1985)). In Boehm, Justice Dickson wrote:

Because the "intent of the framers of the Constitution is paramount in determining the meaning of a provision," Eakin v. State ex rel. Capital, 474 N.E.2d 62, 64 (Ind. 1985), this Court will consider "the purpose which induced the adoption," id. at 65, "in order that we may ascertain what the particular constitutional provision was designed to prevent." Northern Ind. Bank and Trust Co. v. State Bd. of Fin. of Ind., 457 N.E.2d 527, 529 (Ind. 1983).

675 N.E.2d at 321. In Eakin, Chief Justice Givan wrote: "The intent of the framers of the Constitution is paramount in determining the meaning of a provision. To properly determine the meaning of a provision the Court should consider the purpose which induced the adoption." 474 N.E.2d at 64-65 (internal citations omitted).

69. McIntosh, 729 N.E.2d at 986 (quoting Ind. Gaming Comm'n v. Moseley, 643 N.E.2d 296, 298 (Ind. 1994) (citing Price v. State, 622 N.E.2d 954, 957 (Ind. 1993), and State Election Bd. v. 
times, the state of things at the time of framing, "the old law, the mischief, and the remedy"), he quoted Chief Justice Shepard's 1991 Sonnenburg opinion, which quoted Justice Samuel H. Buskirk's 1871 opinion in State v. Gibson. ${ }^{70}$ As authority supporting the fifth element (deferring to the particular constitutional

Bayh, 521 N.E.2d 1313, 1316 (Ind. 1988)). In Moseley, Chief Justice Shepard wrote: "This Court analyzes questions arising under the Indiana Constitution by examining the language of the text in the context of the history surrounding its drafting and ratification, the purpose and structure of our constitution, and case law interpreting the specific provisions." 643 N.E.2d at 298 (internal citations omitted). In Price, Chief Justice Shepard observed that the court had not yet reviewed the constitutionality of the statute it was considering and had not "had many opportunities to explicate the scope of Article I, § 9," noting that "[c]ommentators [had] opine[d] that our constitution's documentary record leaves few clues about the original understandings of free expression which leavened the text of $\S 9$," and indicated that " $[\mathrm{t}]$ he adoption of $\S 9$ from draft language supplied by the Committee on Rights and Privileges back in 1850 was accompanied by neither debate nor amendment." 622 N.E.2d at 957 . He continued:

The conspicuous absence of documented dissidence notwithstanding, we find ample indicia of the meaning of $\S 9$. Interpretation of the Indiana Constitution is controlled by the text itself, illuminated by history and by the purpose and structure of our constitution and the case law surrounding it. State Election Bd. v. Bayh (1988), Ind., 521 N.E.2d 1313.

Id. In State Election Board, Chief Justice Shepard quoted the text of the constitutional provision that the court was asked to interpret and apply, and then he stated:

The framers left us little to discern their intention about the meaning of the phrase "resident of the State." The history of this provision, the purpose of the residency requirement, and the caselaw defining residence in other contexts lead us to interpret "resident of" in art. V, 77 to mean domiciliary.

521 N.E.2d at 1316.

70. McIntosh, 729 N.E.2d at 986 (quoting Sonnenburg, 573 N.E.2d at 412). In Sonnenburg, Chief Justice Shepard wrote:

We have also said that "in placing a construction upon a constitution or any clause or part thereof, a court should look to the history of the times, and examine the state of things existing when the constitution or any part thereof was framed and adopted, to ascertain the old law, the mischief, and the remedy." State v. Gibson (1871), 36 Ind. $389,391$.

573 N.E.2d at 412 . In Gibson, Justice Buskirk wrote:

It is settled by very high authority, that, in placing a construction upon a constitution or any clause or part thereof, a court should look to the history of the times, and examine the state of things existing when the constitution or any part thereof was framed and adopted, to ascertain the old law, the mischief, and the remedy. The court should also look to the nature and objects of the particular powers, duties, and rights in question, with all the light and aids of co[n]temporary history, and give to the words of each provision just such operation and force, consistent with their legitimate meaning, as will fairly secure the end proposed.

36 Ind. 389, 391-92 (1871) (citing Prigg v. Pa., 41 U.S. (16 Pet.) 539 (1842), and Kendall v. United States, 37 U.S. (12 Pet.) 524 (1838)). 
language), he quoted Chief Justice Curtis G. Shake's 1940 opinion in Warren v. Indiana Telephone Co. ${ }^{71}$

Justice Dickson's opinions in City Chapel, Embry, and Meredith also reveal that the court considers an array of documents and materials in applying this methodology and interpreting the text of the 1851 Indiana Constitution. First, the court studies the text of and the history surrounding the 1816 Indiana Constitution. ${ }^{72}$ Second, the court weighs the relevance of the Northwest Ordinance of 1787 and other state constitutions, especially any language and history that illuminate the meaning of Indiana constitutional provisions. ${ }^{73}$ Third,

71. McIntosh, 729 N.E.2d at 986 (quoting Warren v. Ind. Tel. Co., 26 N.E.2d 399, 403 (Ind. 1940)). In Warren, Chief Justice Shake wrote:

These provisions of the Constitution are a part of the fundamental law of the state, declared by the people themselves acting in their sovereign capacity. Ellingham v. Dye, 1912, 178 Ind. 336, 99 N.E. 1, Ann.Cas.1915C, 200. As such they are entitled to strict construction. Lafayette, Muncie, \& Bloomington R. Co. and Another v. Geiger, 1870, 34 Ind. 185. It has been said that the language of each provision of the Constitution is to be considered as though every word had been hammered into place. State ex rel. Hovey v. Noble, 1889, 118 Ind. 350, 353, 21 N.E. 244, 4 L.R.A. 101, 10 Am.St. Rep. 143.

26 N.E. 2 d at 403 .

72. In City Chapel, Justice Dickson noted similarities and differences between article 1, sections 2, 3, and 4 of the 1851 Indiana Constitution and the provisions of Indiana's 1816 Constitution, finding that the provisions do "not differ substantially" from the 1816 Indiana Constitution. City Chapel Evangelical Free Inc. v. City of S. Bend, 744 N.E.2d 443, 447 \& n.5 (Ind. 2001). In his Embry opinion, Justice Dickson reviewed the religious freedom provisions of Indiana's 1816 Constitution and noted that the language found in article 1, section 6 of the 1851 Indiana Constitution did not appear in the 1816 Indiana Constitution. Embry v. O'Bannon, 798 N.E.2d 157, 160 \& n.2 (Ind. 2003) (quoting IND. Const. art. 1, § 3 (1816)). Additionally, in his effort to discern the intended meaning of the framers of the 1816 Indiana Constitution, Justice Dickson has consulted the 1816 Journal of the Convention of the Indiana Territory. See, e.g., Mitchell v. State, 745 N.E.2d 775, 786 \& n.9 (Ind. 2001) (citing JouRNAL OF THE CONVENTION OF THE INDIANA TERRITORY, 1816, at 63 (1816), reprinted in 61 IND. MAG. Hist. 77 (1965)).

73. In Embry, Justice Dickson considered the counterpart provisions of two state constitutions that the framers of Indiana's 1851 Constitution had expressly referenced in adopting new religion provisions that had not appeared in the 1816 Indiana Constitution. 798 N.E.2d at 161-62, 165-66 (quoting and discussing Mich. Const. of 1835, art. I, § 5; Wis. Const. art. I, § 18; State ex rel. Johnson v. Boyd, 28 N.E.2d 256, 261, 265-67 (Ind. 1940); Ctr. Twp. of Marion Cty. v. Coe, 572 N.E.2d 1350, 1352, 1360 (Ind. Ct. App. 1991); Dep't of Nat. Res. v. Bd. of Tr. of Westminster Church of Detroit, 318 N.W.2d 830, 831-32 (Mich. Ct. App. 1982); Op. re Constitutionality of P.A. 1970, No. 100, 180 N.W.2d 265, 270, 274 (Mich. 1970); State ex rel. Warren v. Nusbaum, 219 N.W.2d 577, 585 (Wis. 1974); State ex rel. Warren v. Nusbaum, 198 N.W.2d 650, 659 (Wis. 1972)). In Meredith, Justice Dickson noted the similarities in the language of the education provision of article 8, section 1 of Indiana's 1851 Constitution and its predecessor provisions in Indiana's 1816 Constitution and the Northwest Ordinance of 1787. Meredith v. Pence, 984 N.E.2d 1213, $1221 \&$ n.11 (Ind. 2013). 
it considers the United States Constitution. ${ }^{74}$ Fourth, the court consults the Journal of the Convention of the People of the State of Indiana from the 18501851 Indiana Constitutional Convention and the Report of the Debates and Proceedings of the Convention for the Revision of the Constitution of the State of Indiana. ${ }^{75}$ Fifth, it draws insight from contemporaneously published materials, such as dictionaries and newspapers. ${ }^{76}$ Sixth, the court consults additional primary source materials and secondary literature, such as Charles Kettleborough's multivolume Constitution Making in Indiana and accounts of Indiana's history. ${ }^{77}$ Nevertheless, although the court may take into account sources such as the Report

74. In City Chapel, Justice Dickson contrasted the text of the First Amendment to the United States Constitution with the seven separate religion provisions in the Indiana Bill of Rights and found that the framers and the ratifiers "did not copy or paraphrase the 1791 language of the federal First Amendment" and that Indiana's religious liberty provisions "were not intended merely to mirror the federal First Amendment." 744 N.E.2d at 445-46 \& nn.3-5. In Meredith, he noted that when the framers and the ratifiers adopted article 1, section 6 of the 1851 Indiana Constitution, "they were crafting the sole limits upon state government with respect to religion." 984 N.E.2d at 1230. He added that the United States Constitution "was not a factor" because the First Amendment "had not yet been extended to apply to state government." Id.

75. In City Chapel, Justice Dickson consulted both of these sources. 744 N.E.2d at 447-48 (quoting and citing Journal of the Convention of the People of the State of Indiana 165 (1936) (1851) [hereinafter Journal]; 1 Report of the Debates and Proceedings of the Convention for the Revision of the Constitution of the State of Indiana 965 (1935) (1850) [hereinafter REPORT]). In Embry, he consulted the 1851 Journal. 798 N.E.2d at 161.

76. In City Chapel, Justice Dickson consulted the definitions of "secure" and "worship" in a dictionary published around the time of the 1850-1851 Indiana Constitutional Convention to understand how the framers would have defined these terms. 744 N.E.2d at 448 (quoting NOAH Webster, An American Dictionary of the English LANGUAge 1000, 1273 (George \& Charles Merriam eds., 1856)). In Embry, he consulted that same dictionary for a definition of the word "ministry." 798 N.E.2d at 161 (quoting WeBster, supra, at 716). In Meredith, he returned to the definitions of the terms "worship" and "ministry" and reviewed the dictionary definition of "ministry" discussed in his Embry opinion. 984 N.E.2d at 1226 (quoting Embry, 978 N.E.2d at 161 (quoting WeBSTER, supra)).

77. In City Chapel, Justice Dickson consulted Kettleborough's work and several other historians. 744 N.E.2d at 448-49 (citing Charles Kettleborough, Constitution MaKing in INDIANA 1780-1851, at 65 (1916); L.C. RUdOLPH, HOOSIER FAITHS: A HiSTORY OF INDIANA'S Churches And Religious Groups x (1995); James H. Madison, The Indiana Way 98-104 (1986)). Likewise, in his Embry opinion, he consulted the work of several historians. See 798 N.E.2d at 162, 164 (citing Donald F. CARmony, Indiana, 1816-1850: The Pioneer Era 363 (1998); RudolPh, supra, at 29; EMma Lou ThORNBROUGH, INDIANA IN THE CIVIL WAR ERA: 18501880, at 60-61 (1966)). In Meredith too, he consulted the work of historians. See 984 N.E.2d at 1230 (quoting and citing An Act to Provide for a General System of Common Schools, [etc.], 1865 Ind. Acts 1, § 167, reprinted in Edwin A. Davis, Statutes of THE StATE of Indiana 815 (1876); Richard G. Boone, A History of EduCAtion in Indiana 267 (1892); Martha McCarthy \& Ran Zhang, The Uncertain Promise of Free Public Schooling, in The History of Indiana Law 213, 226-27 (David J. Bodenhamer \& Hon. Randall T. Shepard eds., 2006)). 
of the Debates and Proceedings of the Convention and the remarks of the delegates recorded there to "amplify [its] understanding of the framers" purposes," such remarks "do not alter the literal meaning of the text of" constitutional provisions. ${ }^{78}$ In all cases, the text remains the "primary source for discerning the common understanding of the framers and ratifiers."

\section{THE INTERPRETATION OF INDIANA'S RELIGION PROVISIONS}

\section{A. Indiana's Religion Provisions Generally}

Before turning to Justice Dickson's interpretation of specific religion provisions of the Indiana Constitution, we will first consider what his opinions in City Chapel, Embry, and Meredith said about the religion provisions generally. In his City Chapel opinion, Justice Dickson began by focusing on the language of the religious freedom provisions of the 1851 Indiana Constitution. ${ }^{80} \mathrm{He}$ noted that the drafters and the ratifiers of the Indiana religion provisions "did not copy or paraphrase the 1791 language of the federal First Amendment," ${ }^{, 1}$ which provides that Congress "shall make no law respecting an establishment of religion, or prohibiting the free exercise thereof." ${ }^{\prime 2}$ Rather, they "adopted seven separate and specific [religion] provisions" in the 1851 Indiana Constitution, ${ }^{83}$ taking several of them from provisions of the 1816 Indiana Constitution. ${ }^{84}$ Finding that Indiana's religious freedom provisions "were not intended merely to mirror the federal First Amendment," equated with" the federal provisions and that First Amendment jurisprudence should not "govern[] the interpretation of our state guarantees."

Also in City Chapel, Justice Dickson, after noting the differences in language between the Indiana religion provisions and the First Amendment, placed Indiana's religion provisions in the broader context of the Indiana Constitution's purpose and structure. He noted the Indiana Constitution's recognition of the state's police power in article 1, section 1, which declares that government is instituted for the "peace, safety, and well-being" of the people, ${ }^{87}$ and the Preamble to the Indiana Constitution, which declares that the constitution has been ordained to establish justice, maintain public order, and perpetuate liberty. ${ }^{88} \mathrm{He}$ observed

78. City Chapel, 744 N.E.2d at 447.

79. Id. at 448 .

80. Id. at $445-46$.

81. Id.

82. U.S. CONST. amend. I.

83. City Chapel, 744 N.E.2d at 446.

84. Id. at $447 \&$ n.5.

85. Id. at 446.

86. Id. In City Chapel, he also observed that section 5 of the Indiana Constitution is similar, but not identical, to its federal counterpart in Article VI of the U.S. Constitution. Id. at 446 n.4.

87. IND. CONST. art. $1, \S 1$.

88. InD. CONST. pmbl. 
that the state's police power includes the power of eminent domain, and he noted that Indiana's "takings" provision (article 1, section 21) acknowledges this government power by implication. ${ }^{89}$ Recognizing the conflict between the government's exercise of its police power and the constitutionally-safeguarded liberties related to religion, he turned to the analytical framework approved by the court in Price v. State and Whittington v. State for resolving such conflicts. ${ }^{90}$ From his discussion of the Price analysis, Justice Dickson then proceeded to his consideration of the three state constitutional provisions at issue in the City Chapel case. ${ }^{91}$

In Embry, Justice Dickson discussed historical facts related to the adoption of the seven religion provisions that he had not discussed in his City Chapel opinion, including the processes by which the provisions were introduced and considered in the 1850-1851 Indiana Constitutional Convention and the vote approving the provisions. ${ }^{92}$

In Meredith, Justice Dickson emphasized the importance of not conflating separate religion provisions and the need to recognize the distinct objectives the framers had in mind when drafting separate religion provisions. ${ }^{93}$ In discussing article 1 , sections 4 and 6 , he observed that the distinctions in language between those sections were "purposeful" and that these provisions "were drafted to specify separate and distinct objectives in their respective restraints upon government." The language distinctions between sections 4 and 6 thus show, Justice Dickson concluded, that the framers and the ratifiers intended to provide distinct protections for religious liberty through their drafting and approval of separate provisions. ${ }^{95}$

\section{B. Article 1, Section 2}

Article 1, section 2 declares, "All [people] shall be secured in the natural right to worship ALMIGHTY GOD, according to the dictates of their own consciences. ${ }^{" 16}$ In City Chapel, Justice Dickson studied two terms that the framers included in this provision, "secured" and "worship." 97 From his examination of the Report of the Debates and Proceedings of the Convention, he found that the delegates to the 1850-1851 Indiana Constitutional Convention considered a proposal to use the term "possess" instead of the words "be secured," but that

89. City Chapel, 744 N.E.2d at 446.

90. Id. at 446-47 (discussing Whittington v. State, 669 N.E.2d 1363, 1368 (Ind. 1996); Price v. State, 622 N.E.2d 954, 960 n.7 (Ind. 1993)).

91. Id. at 447-50.

92. Embry v. O'Bannon, 798 N.E.2d 157, 161 (Ind. 2003).

93. Meredith v. Pence, 984 N.E.2d 1213, 1225-26 (Ind. 2013).

94. Id. at 1226.

95. Id.

96. InD. CONST. art. $1, \S 2$.

97. 744 N.E.2d at 447-48. 
they ultimately rejected that proposal. ${ }^{98}$ In discussing the term "secured," he noted the remarks of two particular delegates (Delegate Robert Dale Owen, the chair of Committee on Rights and Privileges, and Delegate John B. Howe) who emphasized the legislature's duties under this provision to enact law to prevent any "religious society from being disturbed in [its] worship" and to recognize and protect "by proper legislation" the right to worship according to one's own creed. ${ }^{99}$ Based upon his review of a contemporaneously-published dictionary, he found that the term "secure" means (both then and now) "[t]o make certain, to put beyond hazard." ${ }^{\circ 00}$ Looking at the same contemporaneously-published dictionary, he also noted that the term "worship" means "chiefly and eminently, the act of paying divine honors to the Supreme Being; or the reverence and homage paid to him in religious exercises consisting in adoration, confession, prayer, thanksgiving, and the like.... To perform acts of adoration; to perform religious service." ${ }^{101}$ In City Chapel, Justice Dickson did not address the meaning of some of the other language in the provision, ${ }^{102}$ such as what the framers and the ratifiers specifically meant by "the natural right to worship" 103 or "according to the dictates of their own consciences." 104

\section{Article 1, Section 3}

Article 1, section 3 declares, "No law shall, in any case whatever, control the free exercise and enjoyment of religious opinions, or interfere with the rights of conscience." ${ }^{105}$ In City Chapel, Justice Dickson noted that the 1850-1851 Indiana Constitutional Convention adopted section 3 as the Committee on Rights and Privileges had proposed it without debate. ${ }^{106}$ Nevertheless, he found the text clear and unequivocal, and he observed that the phrase "in any case whatever" demonstrates the framers' and ratifiers' intent to provide unrestrained protection for the articulated values." ${ }^{107} \mathrm{He}$ then considered various historical resources to gain insight regarding religion and religious practice in nineteenth-century Indiana, and he noted that religious worship and the exercise of religious opinion were collective activities "practiced in diverse traditions by a variety of religious denominations." $108 \mathrm{He}$ also noted that the section 7 prohibition against a person being "rendered incompetent as a witness, in consequence of his opinions on matters of religion" and the section 8 constitutional requirement that "[t]he mode

\section{Id.}

99. Id. at 448 (quoting REPORT, supra note 75 , at 965 ).

100. Id. (quoting WeBSTER, supra note 76, at 1000).

101. Id. (quoting WeBSTER, supra note 76, at 1273 (emphasis omitted)).

102. See id. at 444-58.

103. IND. CONST. art. $1, \S 2$.

104. Id.

105. Id. art. $1, \S 3$.

106. 744 N.E.2d at 448.

107. Id. (quoting IND. Const. art. $1, \S 3$ ).

108. Id. 
of administering an oath or affirmation shall be such as may be most consistent with, and binding upon, the conscience of the person, to whom such oath or affirmation may be administered" underscore the respect the framers and the ratifiers had for the variety of religious opinions and practices that were flourishing in Indiana by the middle of the nineteenth century. ${ }^{109}$

Justice Dickson also consulted historical sources regarding the adoption of religious liberty provisions in other states at the end of the eighteenth century and the beginning of the nineteenth century, noting similarities and differences in terminology. ${ }^{10}$ Additionally, he noted that in Smith v. Pedigo, one of the Indiana Supreme Court's earliest interpretations of Indiana's religion provisions, the court emphasized that both belief and practice were within the scope of the religious liberty protections of the Indiana Bill of Rights. ${ }^{111}$ The Smith court, he wrote, had "generally observed that the religious liberty clauses 'take away all power of the State to interfere with religious beliefs' and that, 'in other words, the law allows every one [sic] to believe as he pleases, and practice that belief so long as that practice does not interfere with the equal rights of others." "112

Having studied the text, convention materials, and other historical resources, he found that the framers and the ratifiers did not intend the religious freedom provisions "to afford only narrow protection for a person's internal thoughts and private practices of religion and conscience." ${ }^{\prime 13}$ Rather, he continued,

By protecting the right to worship according to the dictates of conscience and the rights freely to exercise religious opinion and to act in accord with personal conscience, Sections 2 and 3 advance core values that restrain government interference with the practice of religious worship, both in private and in community with other persons. ${ }^{114}$

\section{Article 1, Section 4}

Article 1, section 4 declares, "No preference shall be given, by law, to any creed, religious society, or mode of worship; and no person shall be compelled to attend, erect, or support any place of worship, or to maintain any ministry, against his consent." 115 Justice Dickson explored the meaning of the second clause of this provision in City Chapel and Meredith. ${ }^{116}$

In City Chapel, Justice Dickson observed that recorded debates at the 1850-

109. Id. at 449 (quoting IND. ConST. art $1, \S \S 7,8$ ).

110. Id.

111. Id. (citing Smith v. Pedigo, 33 N.E. 777, 779 (Ind. 1893)).

112. Id. (quoting Smith, 33 N.E. at 779).

113. Id. at 450 .

114. Id.

115. InD. ConsT. art. $1, \S 4$.

116. Although Justice Dickson quoted the full provision in his City Chapel and Meredith opinions, he did not undertake to interpret the first clause of article 1, section 4. City Chapel, 744 N.E.2d at 447-50; Meredith v. Pence, 984 N.E.2d 1213, 1225-27 (Ind. 2013). 
1851 Indiana Constitutional Convention provide little guidance to amplify the court's understanding of the language of section $4 .{ }^{117}$ Consequently, his consideration was guided by the constitutional text, which he noted is the "primary source" for "discerning the common understanding of the framers and ratifiers." 118 Applying the Price/Whittington framework, ${ }^{119}$ he concluded that section 4 , together with sections 2 and 3 , advance core constitutional values that government in Indiana may not materially burden. ${ }^{120}$

In Meredith, Chief Justice Dickson noted that the court in City Chapel had determined that the Indiana religion provisions were not intended to mirror the First Amendment and that section 4 was adapted from the 1816 Indiana Constitution. ${ }^{121} \mathrm{He}$ explained that section 4 "explicitly prohibits a person from being 'compelled to attend, erect, or support' a place of worship or a ministry against his consent." 122 Section 4, which he insisted must not be conflated with section $6,{ }^{123}$ restrains government "compulsion of individuals to engage in religious practices absent their consent." ${ }^{124}$ Thus, unlike section 6 , which limits "the government's taxing and spending related to religious matters" and prohibits "expenditures to benefit religious or theological institutions," section 4 prohibits "compulsion of individuals related to attendance, erection, or support of places of worship or ministry." 125 The term "worship," he noted, is "a distinctively ecclesiastical function," and drawing upon what he wrote in his Embry opinion, he observed that the term "ministry" includes within its denotative meaning ecclesiastical functions or profession and agency or service of ministers of the gospel, clergy, priests, apostles, and evangelists. ${ }^{126} \mathrm{He}$ thus concluded that the protections of religious liberty recognized in section 4 and its prohibition against government compulsion of individuals were "neither intended nor understood to limit government expenditures, which [are] addressed by Section 6." ${ }^{127}$ Indiana's school voucher program, he found, did not violate article 1 , section 4 by compelling any person to engage in religious practices, support any place of worship, or maintain any ministry. ${ }^{128}$

\section{E. Article 1, Section 6}

Article 1, section 6 declares, "No money shall be drawn from the treasury, for

117. 744 N.E.2d at 447 .

118. Id. at 448 .

119. See supra note 90 and accompanying text and infra Part V.B.2.

120. City Chapel, 744 N.E.2d at 450.

121. 984 N.E.2d at 1225.

122. $I d$.

123. Id.

124. Id. at 1226.

125. Id.

126. Id.

127. $I d$.

128. Id at 1225-26. 
the benefit of any religious or theological institution." ${ }^{129}$ Justice Dickson explored the meaning of this provision in Embry and Meredith.

In Embry, Justice Dickson studied the text and noted that the language of this provision did not appear in the 1816 Indiana Constitution and that the provision resulted from the 1850-1851 Indiana Constitutional Convention. ${ }^{130} \mathrm{He}$ also noted that the available historical record from the convention did not reflect any substantive discussion regarding section $6 .{ }^{131}$

He found, however, that the address of Delegate Robert Dale Owen, the chair of the Committee on the Rights and Privileges, given at the end of the Indiana Constitutional Convention, provided insight into the intentions of the framers. In this address, Owen explained:

In addition to the guarantees [that] find a place in the old Constitution, to secure the rights of conscience and prevent the imposition, on the citizen, of any tax to support any ministry or mode of worship against his consent, it is provided, that no person shall be rendered incompetent as a witness, in consequence of his opinions in matters of religion; and that no money shall be drawn from the treasury for the benefit of any religious or theological institution. Both these provisions are found in the constitutions of Michigan, Wisconsin, and others of recent date. ${ }^{132}$

Justice Dickson observed that Owen's remark about the aim of preventing the imposition of any tax to support any ministry or mode of worship did "not expressly include or make any reference to educational institutions with religious affiliations." 133 Additionally, because the term "ministry" was defined at the time of the convention to mean ecclesiastical function or profession and agency or service of a minister, a clergyperson, a priest, an apostle, or an evangelist, the framers may have "intended Section 6 to prohibit public funds only for ecclesiastical functions." 134

Justice Dickson next compared the language of section 6 with counterpart provisions of the Wisconsin Constitution and the Michigan Constitution, which Owen had referenced in his address, and noted that the Indiana provision excluded terminology included in both of the other two state constitutions regarding "religious or theological seminaries." 135 This exclusion, Justice Dickson thought, "may indicate that [the framers] did not intend [the Indiana provision] to apply to religious schools." 136 In other words, the framers may not have intended for the words "any religious or theological institution" to include

129. IND. CONST. art. $1, \S 6$.

130. Embry v. O’Bannon, 798 N.E.2d 157, 160-61 (Ind. 2003).

131. Id. at 161 .

132. Id. (quoting JOURNAL, supra note 75 at 964 ).

133. $I d$.

134. Id. (citing WEBSTER, supra note 76, at 716).

135. Id. at 161-62.

136. Id. at 162 . 
religious schools. ${ }^{137}$

Justice Dickson then undertook a careful review of the history of primary and secondary education in Indiana in the first half of the nineteenth century. ${ }^{138}$ This historical survey included consideration of Indiana's 1816 Constitution, private and public school education, public education reform efforts, the adoption of article 8 (the Education Article) in Indiana's 1851 Constitution, and the antiimmigrant and anti-Catholic sentiment that predominated outside Indiana during this period but was muted in Indiana. ${ }^{139}$ Ultimately, Justice Dickson determined that the court did not need to decide "whether the framers and ratifiers intended Section 6 to apply to religious schools" because the case could be resolved on another basis. ${ }^{140}$

That other basis was the "for the benefit of" language of section 6 , and the specific question was whether the dual-enrollment program "confer[red] substantial benefits upon the participating parochial schools" or "directly fund[ed] activities of a religious nature." 141 Justice Dickson determined:

Neither the text of Section 6 nor the circumstances surrounding its adoption ... provide guidance as to whether the phrase "for the benefit of" in Section 6 was intended to erect an absolute prohibition against any expenditure of public money that might confer merely pecuniary incidental benefit to a religious institution. ${ }^{142}$

Justice Dickson then turned to two prior Indiana cases for guidance: State ex rel. Johnson v. Boyd ${ }^{143}$ and Center Township v. Coe. ${ }^{144}$ He found that the courts in those cases had determined that section 6 was not violated either by an arrangement between a municipal government and parochial schools to conduct public schools in parochial school buildings with parochial school staff hired by the public schools or by agreements between a municipal government and religious mission shelters to provide services to the township's homeless. ${ }^{145}$

After discussing these two Indiana cases, Justice Dickson considered how courts in Wisconsin and Michigan had interpreted and applied the counterpart provisions of their state constitutions. ${ }^{146} \mathrm{He}$ found that the courts in those states had determined that their state constitutions were not violated in several situations when the benefits to the church-related institution or the religious organization are incidental or the principal or primary effect is not to advance religion. ${ }^{147}$

137. Id.

138. Id. at $162-64$.

139. Id.

140. Id. at 164 .

141. Id.

142. Id.

143. 28 N.E.2d 256 (Ind. 1940).

144. 572 N.E.2d 1350 (Ind. Ct. App. 1991).

145. Embry, 798 N.E.2d at 164-65.

146. Id. at $165-66$.

147. Id. 
Those permissible situations were: (1) a statute authorizing payment of public funds pursuant to a contract with a church-related university to provide services; (2) a statute authorizing public school boards to contract with private educational providers (including religious organizations) for the provision of special educational services; (3) a statute authorizing public school teachers to be paid with public funds to teach secular subjects in private schools; and (4) an agreement between a government agency and a church to lease property for valid consideration. ${ }^{148}$ He concluded that the courts in Wisconsin and Michigan in these cases reached interpretations consistent with the decisions reached in the two Indiana cases (Boyd and Coe). ${ }^{149}$

Justice Dickson then compared the benefits received by Indiana children, the state, and public school systems with the benefits received by parochial schools under the dual-enrollment program. ${ }^{150} \mathrm{He}$ found that, from the program, Indiana children receive significant educational benefits, the State of Indiana receives the benefit of attaining its educational objectives, and the public school systems receive benefit in the form of additional funding. ${ }^{151}$ As to the benefits received by parochial schools, he found that "any alleged 'savings' to parochial schools and their resulting opportunities for curriculum expansion would be, at best, relatively minor and incidental benefits of the dual-enrollment program." 152 Accordingly, he concluded that the program did not confer substantial benefits upon any religious or theological institution or directly fund activities of a religious nature, and thus, that the program did not violate section $6 .{ }^{153}$

In his Meredith opinion, Chief Justice Dickson's discussion of section 6 built upon his discussion of section 4 , and he observed that "the framers crafted Section 6 [to restrain] government not as to its compulsion of individuals, but rather its expenditure of funds for certain prohibited purposes." ${ }^{154}$ Thus, distinct from section 4, which prohibits government compulsion to engage in religious practices absent consent, section 6 applies to government "taxing and spending related to religious matters" and prohibits "expenditures to benefit religious or theological institutions." 155

Chief Justice Dickson determined that "Section 6 prohibits government expenditures that directly benefit any religious or theological institution" and that "[a]ncillary indirect benefits to such institutions do not render improper those

148. Id. (citing and quoting Dep't of Nat. Res. v. Bd. of Tr. of Westminster Church of Detroit, 318 N.W.2d 830 (Mich. Ct. App. 1982); Advisory Op. re Constitutionality of P.A.1970, No. 100, 180 N.W.2d 265 (Mich. 1970); State ex rel. Warren v. Nusbaum, 219 N.W.2d 577 (Wis. 1974); State ex rel. Warren v. Nusbaum, 198 N.W.2d 650 (Wis. 1972)).

149. Id. at 166.

150. Id. at $166-67$.

151. Id. at 167 .

152. Id.

153. Id.

154. Meredith v. Pence, 984 N.E.2d 1213, 1226 (Ind. 2013).

155. Id. 
government expenditures that are otherwise permissible." ${ }^{156}$ In doing so, he clarified the court's holding in Embry, which he acknowledged was less than plain and somewhat inconclusive. The term "substantial benefits" in his Embry opinion, he stated, was not intended to "denote a measurable line after which any benefit to a religious or theological institution becomes unconstitutional."157 Rather, that phrase, in context, was used in determining the primary or direct beneficiary of the program. ${ }^{158} \mathrm{He}$ also noted that religious institutions may derive substantial benefits from municipal fire, police, water, sewage, and other such services, and he found it "inconceivable that the framers and ratifiers intended to expansively prohibit any and all government expenditures" from which such institutions may derive a benefit. ${ }^{159} \mathrm{With}$ such services, he thought, the primary beneficiary is the public, ${ }^{160}$ and any benefit to the religious institution is ancillary and indirect. ${ }^{161}$ Accordingly, he announced that the proper test under section 6 after Meredith is whether the expenditure directly benefits a religious or theological institution. ${ }^{162}$

In the case of the voucher program, he found that the families of eligible students (especially lower-income families) are the direct beneficiaries, that the program does not directly fund any religious activities because no funds are dispersed without the private, independent choice of the parents of eligible students, and that parent participation is entirely voluntary. ${ }^{163}$ Consequently, any benefit that program-eligible schools (both religious and nonreligious) receive derives from the choice of parents and is ancillary and incidental to the benefit conferred on the families of eligible students. ${ }^{164}$

As to the question of whether any of the eligible schools are "religious or theological institution[s]" under section 6, Chief Justice Dickson returned to an issue left unresolved in his Embry opinion. He noted that, in his Embry opinion, he had determined that the primary and secondary education available to Indiana children in the first half of the nineteenth century "was predominantly provided by private or religious entities" and that "the teaching of religious subject matter was an essential component of [a] general education." 165 He also observed that "the framers did not manifest an intent to exclude religious teaching from [] publicly financed schools." 166 In addition to reviewing the historical survey he had conducted in Embry, he noted that the framers and the ratifiers were establishing "the sole limits upon state government with respect to religion" when

156. Id. at 1227 .

157. Id. at 1228 .

158. Id.

159. Id. at 1227 .

160. Id.

161. Id.

162. Id.

163. Id at $1228-29$.

164. Id. at 1229 .

165. Id. at $1229-30$.

166. Id. at 1230 . 
they adopted the Indiana religion provisions because the First Amendment was not yet applicable to the states. ${ }^{167}$

Drawing insight from "the prevailing social, cultural, and legal circumstances when Indiana's Constitution was enacted," Chief Justice Dickson concluded that "Section $6[\mathrm{w}]$ as not intended to prohibit government support of primary and secondary education which at the time included a substantial religious component." $168 \mathrm{He}$ then announced the court's holding that "the phrase "religious or theological institution[s]' in [article 1,] Section 6 of the Indiana Constitution was not intended to, nor does it now, apply to preclude government expenditures for functions, programs, and institutions providing primary and secondary education." 169

The court held that Indiana's Choice Scholarship Program did not violate article 1 , section 6 in either respect. ${ }^{170}$ The program did not confer an unconstitutional benefit because expenditures under the program did not directly benefit religious schools. ${ }^{171}$ Additionally, institutions and programs providing primary and secondary education are not among the religious or theological institutions that government is prohibited from benefiting with government expenditures. ${ }^{172}$

\section{OBSERVATIONS-Justice Dickson's APPLiCATION OF THE COURT'S InTERPRETIVE Method AND Key FeATURES OF THE Indiana Supreme COURT'S RELIGION PROVISIONS JURISPRUDENCE}

Justice Dickson's opinions in City Chapel, Meredith, and Embry reveal his careful application of the court's interpretive method, which it had developed, articulated, and used over many decades. They also reveal a historically and textually informed jurisprudence regarding the religion provisions of the Indiana Constitution. Offered here are some observations regarding his application of the court's interpretive method and key features of his and the court's religion provisions jurisprudence.

\section{A. Justice Dickson's Application of the Court's Interpretive Method}

1. The Central Tasks in Constitutional Interpretation-Understanding the Text and Retrieving the Intended Meaning.-In his opinions in City Chapel, Embry, and Meredith, Justice Dickson diligently applied the court's method of interpreting and applying Indiana's constitutional provisions. His opinions show that he used the court's method to organize and guide his study of the evidence critical to discovering the intended meaning of the constitutional text. In doing so, he gave priority to the constitutional text as the primary source, considered

167. Id.

168. Id.

169. Id.

170. Id. at 1229-30.

171. Id. at 1230 .

172. Id. 
documents and sources that contributed to the establishment of the constitutional text, examined other relevant primary sources to illuminate the meaning of the text in its historical context, and drew on secondary sources. ${ }^{173}$

His opinions in these cases also reveal his underlying belief that the framers crafted the constitutional provisions to have precise meanings. His primary aim in applying the court's method and conducting careful historical investigation was to retrieve from the historically-situated text the meanings intended by the framers and the ratifiers by bridging the two worlds - the world of the framers, the ratifiers, and the constitutional text, and the world of the interpreter. His opinions manifest a confidence that the court's method will help to unlock the intended meanings and allow the court to faithfully apply those intended meanings in contemporary situations.

2. The Rule of Law-Acknowledging That the Judicial Interpreter Is Under Law.- In seeking the understanding of the framers and the ratifiers, Justice Dickson sought to give effect to their intended meanings, and not to innovate or interject his own preferences. This is reflected in Meredith where he wrote:

As a preliminary matter, we emphasize that the issues before this Court do not include the public policy merits of the school voucher program. Whether the Indiana program is wise educational or public policy is not a consideration germane to the narrow issues of Indiana constitutional law that are before us. Our individual policy preferences are not relevant. In the absence of a constitutional violation, the desirability and efficacy of school choice are matters to be resolved through the political process. ${ }^{174}$

His meticulous application of the court's interpretive methodology, his careful study of the relevant primary and secondary materials, and his search for the intended meanings of the framers and the ratifiers thus reflect a desire to give effect to the meanings expressed by others and a conscious effort to set aside personal values and subjective beliefs. In other words, the careful and orderly manner in which he approached the task of constitutional interpretation reveals a commitment to the rule of law and to principles, values, standards, and structures established in the law by others.

3. The Independent Meaning of the State Constitution-Being Faithful to the Meanings Intended by Others.-By diligently searching for the understanding of the Indiana Constitution that was shared by those who framed and those who ratified it, Justice Dickson sought to understand the seven distinct religion provisions of the Indiana Constitution on their own terms. Consequently, in City Chapel, where the parties asked the court to determine whether First Amendment jurisprudence governs the interpretation of Indiana's religion provisions, Justice Dickson studied the Indiana Constitution as fundamental law that is separate from

173. See supra Parts IV.B, IV.C, IV.D, and IV.E. For a discussion of the court's methodology, see supra Part III.

174. 984 N.E.2d at 1216. 
and independent of the United States Constitution. ${ }^{175}$ Because a careful study of the text of Indiana's religion provisions in their historical context revealed that the framers and the ratifiers of the Indiana provisions intended different meanings from those intended by the framers of the First Amendment, Justice Dickson did not hesitate to interpret Indiana's religion provisions differently than the parallel provision of the United States Constitution. ${ }^{176}$ Accordingly, in carefully applying the court's method in these cases, he sought the meanings intended by others as they communicated those meanings in a written text, and thus, he sought to be faithful to the fundamental law of Indiana as declared by the people of Indiana through those who wrote and approved it. ${ }^{177}$

175. On the significance of separateness and independence in state constitutional interpretation, see Mich. v. Long, 463 U.S. 1032, 1040-41 (1983) (“[W]hen . . . a state court decision fairly appears to rest primarily on federal law, or to be interwoven with the federal law, and when the adequacy and independence of any possible state law ground is not clear from the face of the opinion, [the United States Supreme Court] will accept as the most reasonable explanation that the state court decided the case the way it did because it believed that federal law required it to do so. If a state court chooses merely to rely on federal precedents as it would on the precedents of all other jurisdictions, then it need only make clear by a plain statement in its judgment or opinion that the federal cases are being used only for the purpose of guidance, and do not themselves compel the result that the court has reached. . . If the state court decision indicates clearly and expressly that it is alternatively based on bona fide separate, adequate, and independent grounds, [the Court], of course, will not undertake to review the decision."); Michael J. DeBoer, The Right to Remedy by Due Course of Law-A Historical Exploration and an Appeal for Reconsideration, 6 FAULKNER L. REV. 135, 153-54 (2014).

176. See supra Part IV.A. During his tenure on the court, Justice Dickson also determined that other provisions of the Indiana Constitution have meanings that differ from parallel provisions of the United States Constitution. See, e.g., McIntosh v. Melroe Co., 729 N.E.2d 972, 986 (Ind. 2000) (Dickson, J., dissenting) (finding different meanings intended by the framers of article 1, section 12 of the Indiana Constitution and the framers of the Due Process Clause of the Fourteenth Amendment to the United States Constitution); Journal-Gazette Co. v. Bandido's, Inc., 712 N.E.2d 446, 473 (Ind. 1999) (Dickson, J., dissenting) (finding different meanings intended by the framers of article 1, section 9 of the Indiana Constitution and the framers of the Free Speech Clause of the First Amendment to the United States Constitution); Collins v. Day, 644 N.E.2d 72, 75 (Ind. 1994) (finding different meanings intended by the framers of article 1, section 23 of the Indiana Constitution and the framers of the Equal Protection Clause of the Fourteenth Amendment to the United States Constitution).

177. Justice Dickson did not lose sight of the central point established in the preamble to the Indiana Constitution - "WE, the People of the State of Indiana . . ordain[ed] this Constitution" "TO THE END, that justice be established, public order maintained, and liberty perpetuated." IND. Const. prmbl. In City Chapel, Justice Dickson quoted a portion of the Preamble to the Indiana Constitution. City Chapel Evangelical Free Inc. v. City of S. Bend, 446 N.E.2d 443, 446 (Ind. 2001). In his discussion of the state's police power, in which he quoted a portion of article 1 , section 1, he substituted the words "the People's" for the word "their." Id. He wrote that the Indiana Constitution "declares that government is 'instituted for [the People's] peace, safety, and wellbeing." Id. (quoting IND. Const. art. $1, \S 1$ ). Consequently, for Justice Dickson, being faithful to 


\section{B. Key Features of the Court's Religion Provisions Jurisprudence in These Three Cases}

1. The Independence of Indiana's Religion Provisions from the First Amendment.-Among the key features of the court's religion provisions jurisprudence in these cases is the determination that Indiana's seven religion provisions have meanings separate and independent from the meaning of the First Amendment. In City Chapel, Justice Dickson determined that Indiana's religion provisions should not be equated with the parallel federal provision and that First Amendment jurisprudence should not govern the interpretation of Indiana's provisions. Chief Justice Shepard and Justice Rucker concurred with Justice Dickson on this point. ${ }^{178}$

2. Indiana's Religion Provisions and Core Constitutional Values Under Price and Whittington.-Article 1, sections 2, 3, and 4 advance core constitutional values that are safeguarded from government interference under the Price/Whittington framework. Although Justice Dickson dissented in Price and Whittington and expressed his disagreement with Chief Justice Shepard's interpretation of article 1, section 9 (the Indiana Bill of Rights provision recognizing the right to speak, write, and print freely) and the framework articulated in those cases,${ }^{179}$ the court had affirmed and applied the Price analysis in Whittington, ${ }^{180}$ and it had discussed the Price/Whittington framework in other cases. ${ }^{181}$ By the time of City Chapel, nearly a decade had passed since Price was decided, and the Price/Whittington framework had become a part of Indiana constitutional law. ${ }^{182}$ Consequently, Justice Dickson applied the Price/Whittington framework in City Chapel and determined that several of Indiana's religion provisions embody core constitutional values that the government may not materially burden. ${ }^{183}$ Chief Justice Shepard, Justice Boehm, and Justice Rucker agreed with Justice Dickson on this point. ${ }^{184}$

3. The Government's Duty to Secure Religious Freedom.-City Chapel also established that article 1, section 2 of the Indiana Constitution imposes on Indiana government an affirmative duty to recognize the right to worship, and an

the constitutional text by seeking the intended meaning of the framers and the ratifiers is keeping faith with the people of Indiana.

178. See supra Parts II and IV.A. In stating the points on which he agreed with the majority in City Chapel, Justice Boehm may have implicitly agreed with the majority on this point, but his opinion does not make that agreement explicit. See supra Part II.

179. Whittington v. State, 669 N.E.2d 1363, 1371-72 (Ind. 1996) (Dickson, J., dissenting); Price v. State, 622 N.E.2d 954, 967-69 (Ind. 1993) (Dickson, J., dissenting).

180. Whittington, 622 N.E.2d at 1367-71.

181. See, e.g., McIntosh, 729 N.E.2d at 988-89; In re WTHR-TV, 693 N.E.2d 1, 15-16 (Ind. 1998).

182. See supra Parts III, IV.A.

183. See id.

184. See id. 
affirmative duty to secure and protect that right by law. ${ }^{185}$ Thus, Indiana lawmakers have a duty to make that right certain and put it beyond hazard. Chief Justice Shepard and Justice Rucker concurred in Justice Dickson's opinion on this point. ${ }^{186}$

4. The Unrestrained Scope of Religious Freedom Protection.-In City Chapel, the court determined that the framers and the ratifiers of the Indiana religious provision intended to provide unrestrained protection of the values articulated in article 1, section $3 .{ }^{187}$ According to the court, the framers and the ratifiers intended article 1 , sections 2 and 3 to protect the full variety of religious opinions and practices, whether in private or in more public settings. ${ }^{188}$ Chief Justice Shepard, Justice Rucker, and Justice Boehm concurred in Justice Dickson's opinion on this point. ${ }^{189}$

5. The Individual and Corporate Dimensions of Religious Freedom.-City Chapel established that the protections recognized in article 1, sections 2 and 3 extend beyond personal devotional aspects of religion, beyond private beliefs and opinions, and beyond private practices of religious worship, religion, and conscience to the practice of religious worship in community with other persons. ${ }^{190}$ Thus, the religious freedom protections of article 1 , sections 2 and 3 extend to religious opinions and practices both in private settings and in corporate or group settings. ${ }^{191}$ Chief Justice Shepard, Justice Rucker, and Justice Boehm concurred in Justice Dickson's opinion on this point. ${ }^{192}$

6. The Distinct Meanings of Article 1, Sections 4 and 6.-A unanimous court in Meredith established that article 1, section 4 and article 1, section 6 have distinct meanings. ${ }^{193}$ Section 4 focuses on government compulsion of individuals, and it prohibits government compelling individuals to engage in religious practices or to attend, erect, or support places of worship or ministries against their consent. ${ }^{194}$ According to the court, the framers did not intend section 4 to limit government taxing and spending related to religious matters; rather, they intended section 6 to do that. ${ }^{195}$ Thus, distinct from section 4 , section 6 relates to taxing and spending on religious matters and prohibits government expenditures from benefitting religious or theological institutions. ${ }^{196}$

7. Ancillary, Indirect, and Incidental Benefits to Religious Institutions Under Article 1, Section 6.-Article 1, section 6 does not prohibit expenditures of public

185. See supra Parts II, IV.B.

186. See id.

187. See supra Parts II, IV.C.

188. See supra Parts II, IV.B, IV.C.

189. See id.

190. See id.

191. See id.

192. See id.

193. See supra Parts II, IV.D, IV.E.

194. See supra Parts II, IV.D.

195. See supra Parts II, IV.D, IV.E.

196. See id. 
money that confer ancillary, indirect, or incidental benefits on religious institutions. ${ }^{197}$ According to the court, this provision prohibits government expenditures that directly fund activities of a religious nature or directly benefit religious or theological institutions. ${ }^{198}$ The Embry court was divided on aspects of this issue: Justice Rucker concurred in Justice Dickson's opinion; Chief Justice Shepard concurred in the result reached by Justice Dickson; and Justice Boehm (joined by Justice Sullivan) concurred in the result and agreed that the expenditure of public funds for proper educational purposes is "not for the benefit of" a religious institution. ${ }^{199}$ However, a unanimous court in Meredith clarified the article 1, section 6 standard, which now considers whether an expenditure directly benefits a religious or theological institution. ${ }^{200}$ Consequently, under article 1, section 6, Indiana government has considerable latitude to work with religious institutions to serve and meet the needs of the people of Indiana as long as any benefits conferred on a religious or theological institution are merely incidental, ancillary, or indirect. ${ }^{201}$

8. The Scope of the Term "Any Religious or Theological Institution" in Article 1, Section 6.- The court has determined that the religious and theological institutions referenced in article 1, section 6 do not include primary or secondary educational institutions, even when those institutions have a religious affiliation. ${ }^{202}$ Consequently, the article 1 , section 6 prohibition against government expenditures of public funds to benefit religious and theological institutions does not preclude government expenditures for functions, programs, and institutions providing primary and secondary education, even when some religious affiliation is involved. ${ }^{203}$ In Embry, Justice Boehm (joined by Justice Sullivan) expressed disagreement with Justice Dickson's suggestion that the religious and theological institutions referenced in article 1, section 6 might not have been intended to include religious schools, but Justice Dickson (joined by Justice Rucker) determined that the court did not ultimately need to decide that issue. ${ }^{204}$ However, the court did reach that issue in Meredith and unanimously determined that the scope of the term "any religious or theological institution" does not include institutions providing primary and secondary education. ${ }^{205}$

197. See supra Parts II, IV.E.

198. See id.

199. See id.

200. See id.

201. See id.

202. See supra Parts II, IV.E.

203. See id.

204. See id.

205. See id. 